\title{
Denudation rates of the Quadrilátero Ferrífero (Minas Gerais, Brazil): Preliminary results from measurements of solute fluxes in rivers and in situ-produced cosmogenic ${ }^{10} \mathrm{Be}$
}

\author{
André Augusto Rodrigues Salgado a,b,*, Régis Braucher ${ }^{a}$, Fabrice Colin ${ }^{\text {a,c }}$, \\ Hermínio Arias Nalini Jr. ${ }^{\text {b }}$, Angélica Fortes Drummond Chicarino Varajão b, \\ César Augusto Chicarino Varajão ${ }^{\mathrm{b}}$ \\ ${ }^{a}$ CEREGE-Europôle de l'Arbois BP80, 13545 Aix-en-Provence, France \\ ${ }^{\mathrm{b}}$ Departamento de Geologia da Escola de Minas/UFOP, Brasil \\ ${ }^{\mathrm{c}}$ IRD, UR-037 98848 Nouméa, Cedex, New Caledonia
}

Received 17 March 2005; accepted 19 August 2005

Available online 7 November 2005

\begin{abstract}
This paper investigates the denudation rates in the Quadrilátero Ferrífero, Minas Gerais State (Brazil). The aim is to compare chemical weathering rates from measurements of solute fluxes in rivers and long-term mean erosion rates deduced from in situproduced cosmogenic ${ }^{10} \mathrm{Be}$ concentrations measured in fluvial sediments. Both water samples and sediments were collected in fifteen stations (checkpoints) located in four hydrographic basins with low anthropogenic perturbations.

Depending of the type of substratum, three degrees of chemical denudation rates from water samples are observed: (i) high rates in marbles; (ii) medium rates in schists, phyllites, granites, gneisses and migmatites; (iii) low rates in quartzites and itabirites. Preliminary results of long-term erosion rates deduced from in situ-produced ${ }^{10} \mathrm{Be}$ are comparable with those of chemical rates. (C) 2005 Elsevier B.V. All rights reserved.
\end{abstract}

Keywords: Weathering; Denudation; Cosmogenic nuclides; Quadrilátero Ferrífero

\section{Introduction and site description}

Weathering has been a key subject to the understanding of landscape and soil formation in tropical zones. In the Quadrilátero Ferrífero, one of the most

\footnotetext{
* Corresponding author. CEREGE-Europôle de l'Arbois BP80, 13545 Aix-en-Provence, France. Tel.: +33 4429715 09; fax: +33 442971540.

E-mail addresses: salgado@cerege.fr (A.A.R. Salgado), braucher@cerege.fr (R. Braucher), colinf@noumea.ird.nc (F. Colin), nalini@degeo.ufop.br (H.A. Nalini), angelica@degeo.ufop.br (A.F.D.C. Varajão), varajao@degeo.ufop.br (C.A.C. Varajão).
}

important Brazilian mineral provinces, a semi-humid tropical climate predominates over an area of ca. 7200 $\mathrm{km}^{2}$. This area is constituted of four geological groups (Alkmim and Marshak, 1998): (i) the Crystalline Complex, composed of Archean granites, gneisses and migmatites; (ii) the Rio das Velhas Supergroup, composed of quartzites, schists and phyllites which constitute an Archean greenstone belt sequence; (iii) the Minas Supergroup, a Proterozoic metasedimentary sequence; and (iv) the Itacolomi Group formed by Proterozoic quartzites (Fig. 1).

Soils in the Quadrilátero Ferrífero vary according to the type of substratum. Soils are thin on quartzites and 

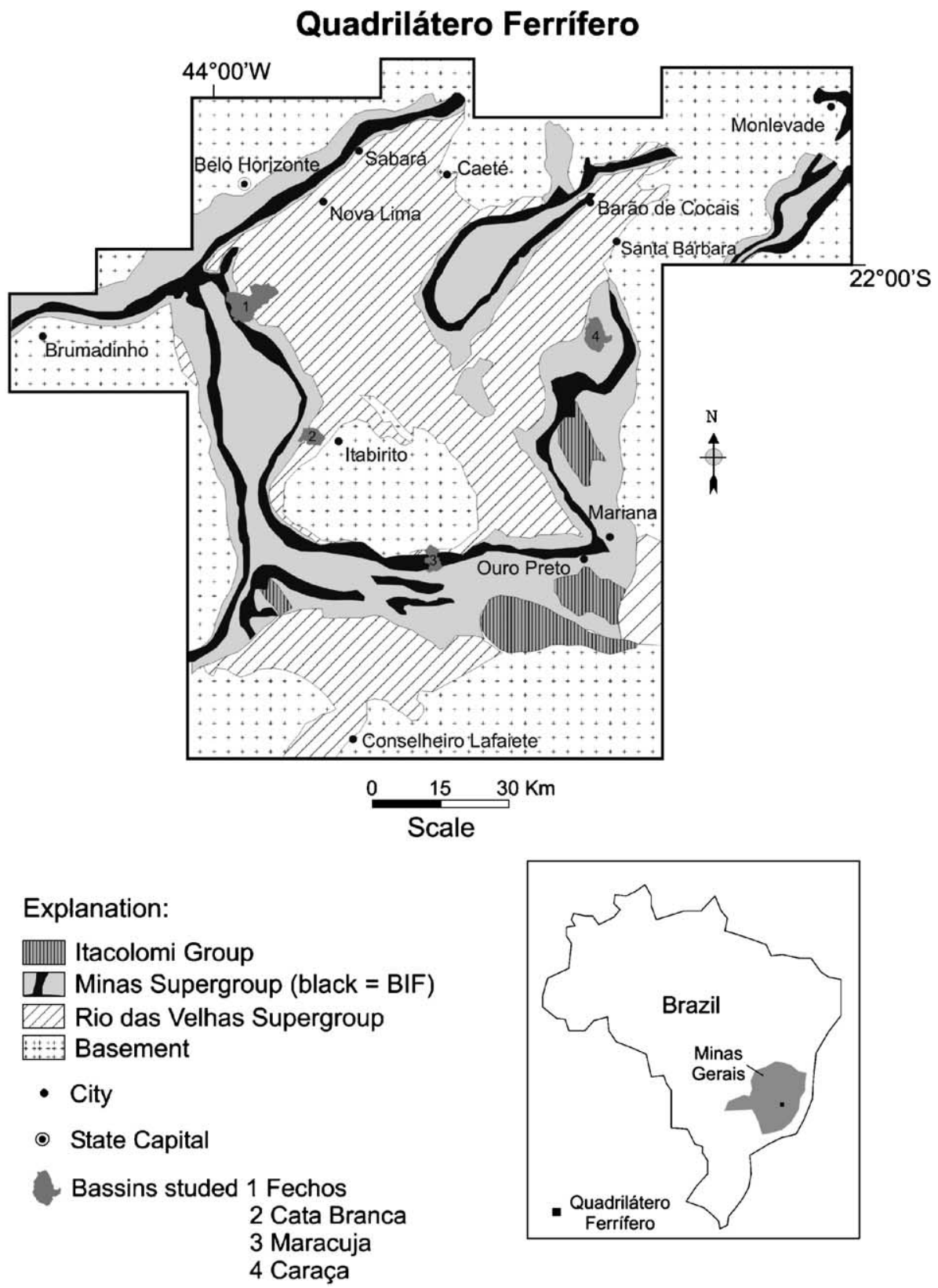

Fig. 1. Localization of the studied basins and geology of Quadrilátero Ferrífero by Alkmim and Marshak (1998).

itabirites (bedrock is usually exposed), whereas on other rock types soils are very thick. The regional vegetation varies with the altitude and with the rock substratum: from grass, in the highest parts, to savanna ("cerrado") to semideciduous forest in the lowest areas (Behling and Lichte, 1997).

The landscape of the Quadrilátero Ferrífero has been interpreted as the result of differential erosion processes where quartzites and itabirites are encountered in the high lands; schists and phyllites in the half- altitude lands, whereas granites, gneisses and migmatites constitute the substratum low lands (Hader and Chamberlin, 1915; King, 1956; Tricart, 1961; Barbosa and Rodrigues, 1967; Varajão, 1991). These studies are only based on field observations and are not supported by quantitative data. In this study, we intend to quantify both chemical weathering rates from measurements of solute fluxes in rivers and long-term mean erosion rates deduced from in situ-produced cosmogenic ${ }^{10} \mathrm{Be}$ concentrations measured in fluvial sediments for dif- 
ferent types of rocks that compose the investigated area.

\section{Methods}

\subsection{Water samples}

To determine the chemical denudation rates in the Quadrilátero Ferrífero, fifteen checkpoints (three in river basins affected by a low anthropogenic activity (High Fechos; Cata Branca/Esperança and High Maracuja), and one pristine environment (Caraça river basin)) were used to collect both water samples and fluvial sediments for cosmogenic analyses (Fig. 1). To perform chemical analyses $(\mathrm{Mn}, \mathrm{Fe}, \mathrm{Mg}, \mathrm{Al}$, $\mathrm{Si}, \mathrm{Ca}, \mathrm{Na}$ and $\mathrm{K}$ ), water samples were collected, in the middle of the stream in 250-ml polyethylene bottles after being filtered at $0.45 \mu \mathrm{m}$. Sampling was done in summer 2003 (humid period) and in winter 2003 (dry period). At the same time, river's discharge was monitored and total dissolved solids (TDS) were measured with a Myron multi-parameter equipment. Chemical analyses were carried out in the Geochemical Laboratory of Geology Department (UFOP), with an ICP-AES Spectro Cirus CCD. Analyses were calibrated directly against the National Institute of Standards and Technology (NIST) standard reference (1643d Trace Elements in Water). The annual chemical denudation was calculated using the equation $T_{\mathrm{D}} / D_{\mathrm{S}} \times A$ where $T_{\mathrm{D}}$ is the total TDS denudation (humid period + dry period), $D_{\mathrm{S}}$, the rock density and $A$ the Basin's Area, determined using a digital elevation model obtained with MicroStation software.

\subsection{Fluvial sediments}

Long-term mean denudation rates were quantified by measurements of in situ-produced ${ }^{10} \mathrm{Be}$ in fluvial sediments. It has been established that cosmogenic ${ }^{10} \mathrm{Be}$ in river-borne quartz sand records a time-integrated erosion rate representative of an entire drainage basin (Brown et al., 1995, 1998).

Quartz was isolated from crushed and sieved sediment samples by dissolving all other minerals with mixtures of $\mathrm{HCl}$ and $\mathrm{H}_{2} \mathrm{SiF}_{6}$. Atmospheric ${ }^{10} \mathrm{Be}$ was then eliminated by successive HF sequential dissolutions. This purified quartz was dissolved in Suprapur $\mathrm{HF}$ and the resulting solution was spiked with $0.3 \mathrm{mg}$ of ${ }^{9} \mathrm{Be}$ carrier. Beryllium was separated from these solutions by successive solvent extractions and precipitations. All ${ }^{10} \mathrm{Be}$ measurements were performed by accelerator mass spectrometry at the Tandétron AMS facility, Gif-sur-Yvette. Measured ${ }^{10} \mathrm{Be} /{ }^{9} \mathrm{Be}$ ratios were calibrated directly against the National Institute of Standards and Technology (NIST) standard reference material SRM 4325 using its certified ${ }^{10} \mathrm{Be} /{ }^{9} \mathrm{Be}$ ratio of $(26.8 \pm 1.4) \times 10-12 .{ }^{10} \mathrm{Be}$ uncertainties $(1 \sigma)$ include a $3 \%$ contribution conservatively estimated from observed standard variations during the runs, a $1 \sigma$ statistical error in the number of ${ }^{10} \mathrm{Be}$ events counted, uncertainty on the blank correction, and a $6 \%$ uncertainty on in situ ${ }^{10} \mathrm{Be}$ production rate within quartz (Stone, 2000).

Table 1

Chemical weathering and long-term erosion rates

\begin{tabular}{|c|c|c|c|c|c|c|}
\hline Basin & Geology $^{\mathrm{a}}$ & Position in the basin & $\begin{array}{l}\text { TDS } \\
\left(\text { ton year }{ }^{-1} \mathrm{~km}^{-2} \text { ) }\right.\end{array}$ & $\begin{array}{l}\text { Area } \\
\left(\mathrm{km}^{2}\right)\end{array}$ & $\begin{array}{l}\text { Chemical weathering } \\
\left(\mathrm{m} \mathrm{Myr}^{-1}\right)\end{array}$ & $\begin{array}{l}{ }^{10} \mathrm{Be} \text { erosion rate } \\
\text { (quartz) }\left(\mathrm{m} \mathrm{Myr}^{-1}\right)\end{array}$ \\
\hline \multirow[t]{3}{*}{ Fechos } & $\mathrm{M}$ and $\mathrm{D}$ & Middle $(1300 \mathrm{~m})$ & 65.76 & 10.17 & $19.52 \pm 5.85$ & $* *$ \\
\hline & $\mathrm{M}$ and $\mathrm{D}$ & Tributary $(1200 \mathrm{~m})$ & 71.75 & 6.41 & $25.35 \pm 7.60$ & $* *$ \\
\hline & $\mathrm{S}, \mathrm{P}, \mathrm{M}, \mathrm{I}, \mathrm{Q}$ & Outlet (958 m) & 55.69 & 26.29 & $17.18 \pm 5.15$ & $* *$ \\
\hline \multirow[t]{4}{*}{ Cata Branca } & $\mathrm{I}, \mathrm{Q}$ & Headwater $(1307 \mathrm{~m})$ & 7.68 & 1.24 & $2.37 \pm 0.71$ & $* *$ \\
\hline & $\mathrm{S}, \mathrm{P}$ & Tributary $(866$ m) & 10.65 & 3.99 & $3.53 \pm 1.06$ & $* *$ \\
\hline & $\mathrm{S}, \mathrm{P}, \mathrm{I}$ and $\mathrm{Q}$ & Middle $(866 \mathrm{~m})$ & 12.26 & 11.47 & $3.91 \pm 1.17$ & $* *$ \\
\hline & $\mathrm{S}, \mathrm{P}, \mathrm{I}$ and $\mathrm{Q}$ & Outlet $(850 \mathrm{~m})$ & 11.37 & 15.46 & $3.69 \pm 1.11$ & $* *$ \\
\hline \multirow[t]{5}{*}{ Maracuja } & $\mathrm{S}, \mathrm{P}$ & Headwater (1332 m) & 24.77 & 0.15 & $8.71 \pm 2.61$ & $* *$ \\
\hline & $\mathrm{S}, \mathrm{P}$ & Tributary $(1175 \mathrm{~m})$ & 27.64 & 0.88 & $9.84 \pm 2.95$ & $10.01 \pm 2.46$ \\
\hline & $\mathrm{S}, \mathrm{P}$ & Middle (1146 m) & 22.51 & 4.98 & $8.01 \pm 2.40$ & $14.70 \pm 5.48$ \\
\hline & $\mathrm{Gr}$ and $\mathrm{Gn}$ & Tributary $(1072 \mathrm{~m})$ & 14.04 & 1.15 & $5.14 \pm 1.54$ & $15.41 \pm 2.33$ \\
\hline & Gr, Gn, I, S, P & Outlet $(1072 \mathrm{~m})$ & 14.90 & 15.37 & $5.48 \pm 1.64$ & $4.32 \pm 1.53$ \\
\hline \multirow[t]{3}{*}{ Caraça } & Q & Headwater $(1281 \mathrm{~m})$ & 9.65 & 3.06 & $3.75 \pm 1.12$ & $1.07 \pm 0.13$ \\
\hline & $\mathrm{Q}$ and $\mathrm{MD}$ & Tributary $(1280 \mathrm{~m})$ & 4.03 & 4.20 & $1.57 \pm 0.47$ & $2.23 \pm 0.17$ \\
\hline & $\mathrm{Q}$ and $\mathrm{M} \mathrm{D}$ & Outlet (1254 m) & 3.34 & 20.29 & $1.3 \pm 0.39$ & $3.18 \pm 0.31$ \\
\hline
\end{tabular}

**= not yet available.

${ }^{a} \mathrm{M}, \mathrm{D}, \mathrm{Q}, \mathrm{Gr}, \mathrm{Gn}, \mathrm{S}, \mathrm{P}, \mathrm{I}, \mathrm{MD}$ refers to marbles, dolomite, quartzite, granite, gneiss, schiste, phyllite, itabirite and mafic dikes, respectively. 


\section{Results and discussion}

From Table 1, one can observe that, from the solute fluxes in river waters, marbles, granites, gneisses, schistes and phyllites constitute the most fragile rocks when exposed to denudation, whereas quartzites and itabirites are the most resistant. However, marbles, granites, gneisses, schistes and phyllites are also present in the highest parts of the studied area. This can be explained by Cenozoic uplifts (Lipski, 2002), as well as by the Precambrian framework, today represented by itabirite and quartzite crests that protect the most fragile rocks from complete denudation, sustaining them in the higher parts of the landscape (Tricart, 1961; Barbosa and Rodrigues, 1967). The most intense chemical denudation takes place in small basins, and the denudation processes tend to be more intense close to the headwaters than in the regional base levels (Summerfield, 1991). A similar high intensity of the denudation processes in tributary basins has been observed in other areas of the globe (Leeder, 1991; Stallard et al., 1991; Milliman and Syvitski, 1992; Edmond et al., 1995).

In Table 1, the long-term erosion rates inferred by in situ-produced ${ }^{10} \mathrm{Be}$ are similar to those of previous studies performed on cratonic environments (Braucher et al., 1998). When compared to the chemical weathering rates deduced from the water samples, and because the Caraça basin, a state natural park, and the Maracuja basin are preserved from anthropogenic activities, one can observe that these long-term denudation rates are in good agreement. This may suggest that denudation is mainly due to chemical weathering. However, one sample from the tributary of the Maracuja basin shows a long-term erosion rate $(15.41 \pm 2.33 \mathrm{~m} / \mathrm{My})$ significantly higher than that given by the water river $(5.14 \pm 1.54$ $\mathrm{m} / \mathrm{My}$ ). This may be explained by an ancient deforestation that took place to allow an agricultural activity (extensive cow breeding). In that case, physical erosion is more intense and does not permit to a surficial disturbed quartz to accumulate as much ${ }^{10} \mathrm{Be}$ as an undisturbed bedrock sample.

\section{Conclusion}

This preliminary study is, to our knowledge, the first that intends to compare chemical weathering rates evaluated in river waters and long-term erosion rates calculated from cosmogenic analyses.

Both approaches demonstrate differential denudation processes controlled by (i) the substrate and (ii) the size of the basin.

\section{Acknowledgments}

The authors would like to present their sincere thanks to CAPES and COFECUB for the financial support (project 406); to MBR (Minerações Brasileiras Reunidas) and Mineração Morro Velho for some rocks samples; to Guilherme Gravina, Fernando Moraes and Cláudio Lana, who helped collecting the water samples; to the Geochemical Laboratory of the Geology Department (UFOP); and special thanks to Janice Cardoso Pereira and Adriana Trópia Guimarães, for the water analyses.

\section{References}

Alkmim, F.F., Marshak, S., 1998. Transamazonian Orogeny in the Southern São Francisco Craton Region, Minas Gerais, Brazil: evidence for Peleoproterozoic collision and collapse in the Quadrilátero Ferrífero. Precambrian Research 90, 29-58.

Barbosa, G.V., Rodrigues, D.M.S., 1967. Quadrilátero Ferrífero, IGC/ UFMG. Belo Horizonte, Brazil. 130 pp.

Behling, H., Lichte, M., 1997. Evidence of dry and cold climatic conditions at glacial times in tropical Southeastern Brazil. Quaternary Research 48, 348-358.

Braucher, R., Bourlès, D.L., Colin, F., Brown, E.T., Boulangé, B., 1998. Brazilian laterite dynamics using in situ-produced ${ }^{10} \mathrm{Be}$. Earth and Planetary Science Letters 163, 197-205.

Brown, E.T., Stallard, R.F., Larsen, M.C., Raisbeck, G.M., Yiou, F., 1995. Denudation rates determined from the accumulation of in situ-produced ${ }^{10} \mathrm{Be}$ in the Luquillo Experimental Forest. Puerto Rico Earth and Planetary Science Letters (193), $193-202$.

Brown, E.T., Stallard, R.F., Larsen, M.C., Bourlès, D.L., Raisbeck, G.M., Yiou, F., 1998. Determination of predevelopment denudation rates of an agricultural watershed (Cayaguás River, Puerto Rico) using in-situ-produced ${ }^{10} \mathrm{Be}$ in river-borne quartz. Earth and Planetary Science Letters 160 (3-4), 723-728.

Edmond, J.M., Palmer, M.R., Measures, C.I., Grant, B., Stallard, R.F., 1995. The fluvial geochemistry and denudation rate of the Guayana Shield in Venezuela, Colombia and Brazil. Geochimica et Cosmochimica Acta 59 (16), 3.301-3.325.

Hader, E.C.R., Chamberlin, T., 1915. The geology of central Minas Gerais. Journal of Geology 23 (445), 341-424.

King, C.L., 1956. A geomorfologia do Brasil Oriental. Revista Brasileira de Geociências 18 (2), 147-265.

Leeder, M.R., 1991. Denudation, vertical crust movements and sedimentary basin infill. Geologische Rundschau 80 (2), 441-458.

Lipski, M., 2002. Tectonismo cenozóico no Quadrilátero Ferrífero, Minas Gerais. Thesis, DEGEO/EM/Universidade Federal de Ouro Preto, Brazil. 171 pp.

Milliman, J.D., Syvitski, J.P.M., 1992. Geomorphic/tectonic control of sediment discharge to the ocean: the importance of small mountainous rivers. The Journal of Geology 100, 525-544.

Stallard, R.F., Koehnken, L., Johnsson, M.J., 1991. Weathering processes and the composition of inorganic material transported through the Orinoco River system, Venezuela and Colombia. Geoderma 51, 133-165.

Stone, J.O., 2000. Air pressure and cosmogenic isotope production. Journal of Geophysical Research 105 (B10), 23753-23759. 
Summerfield, M.A., 1991. Global Geomorphology: An Introduction of the Study of Landforms. Longman Scientific and Technical, Essex, U.K. 537 pp.

Tricart, J., 1961. O modelado do Quadrilátero Ferrífero sul de belo horizonte. Annales de Geographie 379, 255-272.
Varajão, C.A.C.A., 1991. A questão da correlação das superfícies de erosão do Quadrilátero Ferrífero, Minas Gerais. Revista Brasileira de Geociências 21 (2), 138-145. 